\title{
PELATIHAN PENULISAN ARTIKEL HASIL PENELITIAN TINDAKAN KELAS GURU SMPN 1 GRESIK
}

\author{
Eko Cahyo Prawoto'), Taufik Nurhadi' ${ }^{2)}$, Luluk Isani Kulup ${ }^{3)}$, \\ Henricus Supriyanto ${ }^{4)}$, Mimas Ardhianti ${ }^{5}$ ) \\ Fakultas Ilmu Sosial dan Humaniora Universitas PGRI Adi Buana Surabaya; \\ Email : eko.cahyo@unipasby.ac.id, taufiknurhadi70@gmail.com, luluk@unipasby.ac.id, \\ henri_supriyanto@gmail.com, mimasardhianti@gmail.com
}

\begin{abstract}
Abstrak
Guna Untuk meningkatkan publikasi artikel ilmiah hasil PTK, perlu pelatihan dan pendampingan bagi guru-guru dalam menulis artikel ilmiah. Oleh karena itu, kegiatan Pengabdian Pada Masyarakat (PPM) Program Studi Pendidikan Bahasa Indonesia Universitas PGRI Adi Buana Surabaya, semester Gasal 2020/2021 ialah memberikan pelatihan penulisan artikel hasil PTK bagi guru SMPN 1 Gresik. Pelaksanaan program dilakukan melalui kemitraan dengan Guru SMPN 1 Gresik, Kabupaten Gresik. Dalam melaksanakan kegiatan Pelatihan Penulisan Artikel Ilmiah hasil PTK, menggunakan metode direct instruction. Hasil pelatihan yang telah dilakukan pada Guru SMPN 1 Gresik, yang telah dilakukan oleh Pogram Studi Pendidikan Bahasa Indonesia ialah sebagai berikut; 1) hasi pelatihan penyusunan artikel hasil PTK ialah peserta dapat menyusun artikel ilmiah hasil PTK dengan baik. Hal tersebut dapat dibuktikan dari 40 produk artikel yang ditulis oleh Guru SMPN 1 Gresik, yang memenuhi kriteria artikel yang baik dengan memperhatikan aspek pada setiap artikel ialah sebesar 94\%, yang artinya pelatihan sudah mencapai tujuan pelatihan.
\end{abstract}

Kata kunci: Artikel Ilmiah, Penelitian Tindakan Kelas

Abstract

To increase the publication of scientific articles on the results of CAR, training and mentoring are needed for teachers in writing scientific articles. Therefore, the Community Service (PPM) activity of the Indonesian Language Education Study Program, Adi Buana University, Surabaya, Odd semester 2020/2021 is to provide training in writing articles on PTK results for teachers of SMPN 1 Gresik. The program is implemented in partnership with teachers at SMPN 1 Gresik, Gresik Regency. In carrying out the training of scientific article writing on the results of PTK, through the direct instruction method. The results of the training that has been carried out on teachers of SMPN 1 Gresik, which have been carried out by the Indonesian Language Education Study Program are as follows; 1) the result of the training for the preparation of articles on the results of CAR is that participants can compile scientific articles on the results of CAR. This can be proven from the 40 article products written by the teacher of SMPN 1 Gresik, which meet the criteria for good articles by paying attention to the aspects of each article, which is $94 \%$, which means that the training has achieved the training objectives.

Keywords: Scientific Articles, Classroom Action Research

\section{PENDAHULUAN}

Seorang guru professional tentunya harus mampu menyelenggarakan pembelajaran yang sesuai dengan kurikulum, serta sesuai dengan karakteristik pembelajaran dewasa ini. Jika terdapat hasil pembelajaran yang belum sesuai dengan capaian pembelajaran yang telah ditetapkan, seorang guru harus mampu mencari permasalahan yang muncul serta mampu menemukan solusi terhadap permasalahan di kelas.

(Mulia \& Suwarno, 2016) melalui pengalaman dalam mengajar, seorang guru hendaknya mampu mencari permasalahan dan pemecahan permasalahan yang ditemui di kelas, agar masalah tersebut dapat teratasi, sehingga pembelajaran dapat terselenggara menjadi lebih baik lagi, serta dapat mencapai 
tujuan pembelajaran. Di antara upaya yang perlu dilakukan untuk mengetahui penyebab belum tercapainya tujuan pembelajaran, serta upaya perbaikanya ialah melalui penelitian tindakan kelas (PTK).

PTK terdiri dari penelitian, tindakan, dan kelas. Penelitian ialah aktivitas mencermati suatu objek dengan memperhatikan aturan, serta metodologi tertentu, untuk mendaptkan informasi dan data, yang memiliki manfaat untuk meningkatkan mutu suatu aspek. Tindakan ialah upaya yang dilakukan dengan sengaja untuk mecapai tujuan tertentu. Sedangkan, kelas merupakan kelompok siswa yang menerima pembelajaran dari guru pada waktu yang sama. (Slameto, 2016)

Kunandar (Mulia \& Suwarno, 2016), menyatakan PTK adalah kegiatan penelitian yang dirancang, dilaksanakan, dan direfleksi melalui tindakan kolaboratif dan partisipatif, yang dilakukan oleh seorang guru maupun berkolaborasi dengan guru yang lain, dengan tujuan memperbaiki atau meningkatkan kualitas pembelajaran di kelas, dengan suatu tindakan pada suatu siklus.

(Salim, Isran Rasyid K.K, 2013) tujuan dalam melaksanakan penelitian tindakan kelas ialah; a) meningkatkan mutu, saran, melalui proses, serta hasil pendidikan dan pembelajaran, b) meningkatkan kualitas guru dan tenaga kependidikan dalam upaya memecahkan permasalahan pembelajaran di kelas maupun di luar kelas, c) meningkatkan profesionalisme guru serta tenaga kependidikan, d) meningkatkan budaya akademik di sekolah, sehingga dapat menciptakan sikap proaktif sebagai upaya meningkatkan mutu pendidikan.

Suyatno (Mahmud dan Tedi Priatna, 1980) menyatakan, terdapat tiga manfaat yang dapat diperoleh dari kegiatan penelitian tindakan kelas, diantaranya; a) inovasi pada pembelajaran, b) pengembangan kurikulum di tingkat kelas dan di tingkat sekolah, c) peningkatan kompetensi guru.

Selanjutnya melalui kegiatan PTK, seorang guru juga harus dapat mempublikasikan artikel ilmiah hasil PTK. Sebab PTK dan artikel ilmiah menjadi sangat penting bagi guru, sebagai salah satu produk pengembangan diri yang juga dapat digunakan untuk mengembagkan karir yang bersangkutan, Daniel (Hidayah Rusly, Dina Kartika Maharani, 2020)

Sejalan dengan Daniel, Tojirin (Hidayah Rusly, Dina Kartika Maharani,
2020) PTK dan artikel ilmiah merupakan satukesatuan yang sangat penting, bagi guru sebagai upaya aktualisasi diri dalam menjalankan tugas profesinya.

Namun demikian kegiatan menulis artikel PTK nampaknya belum menjadi kebiasaan yang rutin dilakukan oleh guru, sehingga artikel ilmiah hasil PTK yang terpublikasi dengan jumlah guru dan sekolah di Indonesia masih terlalu sedikit.

Melihat fakta tersebut, pemerintah mengeluarkan aturan dengan cara menuntut publikasi ilmiah bagi guru, sebagai syarat wajib untuk kenaikan pangkat. Untuk memperoleh angka kredit tersebut diatur dalam Peraturan Menteri Negara Pendayagunaan Aparatur Negara dan Reformasi Birokrasi Nomor 16 Tahun 2009. Tentang jabatan fungsional Guru dan Angka Kreditnya pada publikasi karya ilmiah (Marwa \& Dinata, 2020). Oleh sebab itu, untuk meningkatkan publikasi artikel ilmiah hasil PTK, perlu pelatihan dan pendampingan bagi guru-guru dalam menulis artikel ilmiah.

Menulis artikel ilmiah merupakan suatu kegiatan menyusun karya tulis nonfiksi, yang berisi gagasan, pemikiran konseptual, pemecahan permasalahan, melalui kegiatan pengamatan, yang kemudian disusun secara sistematis, sesuai kaidah yang ditetapkan Supriyadi, (Dewi et al., 2017).

Sementara itu, menurut Suyanto dan Jihad (Dewi et al., 2017) menulis artikel merupakan kegiatan menyusun hasil pengkajian sistematis melalui metode ilmiah untuk mendapatkan informasi dan data sebagai jawaban ilmiah, terhadap suatu permasalahan yang dipublikasikan pada jurnal. Selanjutnya, (Al Idrus et al., 2020) menyatakan, menulis artikel yang dipublikasikan di jurnal, merupakan salah satu upaya peningkatan kualitas profesi guru, sekaligus dapat meningkatkan kualitas pembelajaran yang disampaikan di dalam kelas.

Sedangkan menurut Maimunah (Dewi et al., 2017) artikel ilmiah merupakan suatu karya tulis yang disusun dan dirancang untuk selanjutnya dimuat pada jurnal maupun pada buku kumpulan artikel. Berdasarkan tiga pendapat tersebut, dapat dipahami bahwa kegiatan menulis artikel merupakan kegiatan menyusun informasi dan data sebagai sebuah jawaban atas permasalahan yang muncul, berdasarkan kerangka konseptual berpikir ilmiah dan metode yang sistematis, yang bersifat empiris dan dapat dibuktikan 
kebenaranya secara ilmiah, yang kemudian dipublikasikan pada jurnal.

Artikel ilmiah yang dipublikasikan pada jurnal diharapkan memenuhi standar. Standar karya ilmiah merupakan cerminan sifat karya ilmiah yang menjunjung norma dan nilai empiris sesuai dengan tradisi yang sudah mengakar, yang dapat dipertangungjawabkan secara ilmiah. Taryadi, (Siregar, 2011)

Berdasarkan latar belakang tersebut, melalui kegiatan Pengabdian Pada Masyarakat (PPM) Program Studi Pendidikan Bahasa Indonesia Universitas PGRI Adi Buana Surabaya, melakukan pelatihan penulisan penulisan artikel hasil PTK bagi guru SMPN 1 Gresik. Pemilihan sekolah tersebut didasarkan pada beberapa hal:

a. Pemahaman tentang penulisan artikel hasil penelitian karya ilmiah masih kurang

b. Minat dan motivasi untuk menulis artikel hasil penelitian PTK karya ilmiah masih rendah

c. Motivasi menulis artikel sangat minim

Berdasarkan hasil pengamatan pada Agustus 2020 di SMPN 1 Gresik, diperoleh informasi di mengenai kondisi tenaga pendidik sebagai berikut.

a. Pengetahuan tentang penulisan artikel hasil PTK: Secara mayoritas Belum semua pendidik memahami tentang penulisan artikel hasil PTK Karya Ilmiah

b. Penulisan artikel ilmiah hasil PTK

c. Penelitian Tindakan Kelas belum dilakukan secara rutin dan berkala

d. Kepangkatan secara mayoritas masih IIIb

e. Belum mimiliki publikasi

f. Jumlah Pendidik: 40 orang

Berdasarkan permasalahan tersebut perlu dilakukan pelatihan penulisan hasil PTK, untuk mengatasi permasalahan pada poin a dan $b$, yaitu memberikan pelatihan guna meningkatkan pemahaman Guru SMPN 1 Gresik dalam penulisan artikel PTK, memberi pelatihan penyusunan artikel ilmiah, serta mendorong Guru SMPN 1 Gresik untuk melakukan publikasi secara rutin.

\section{METODE}

Pelaksanaan program dilakukan melalui kemitraan dengan Guru SMPN 1 Gresik, Kabupaten Gresik. Dalam melaksanakan kegiatan Pelatihan Penulisan Artikel Ilmiah Hasil PTK, melalui direct instruction method, adapun pelaksanaan kegiatan tersebut ialah sebagai berikut; a) penyajian materi tentang Pentingnya Penelitian Tindakan Kelas, b) penyajian materi penulisan artikel ilmiah hasil PTK, c) diskusi mengenai PTK dan artikel hasil PTK, d) praktik menyusun PTK sederhana dan artikel hasil PTK, e) pendampingan publikasi artikel iliah hasil PTK, f) evaluasi kegiatan pelatihan. dalam kegiatan pelatihan diperlukan evaluasi dengan memperhatikan aspek seperti berikut; a) keseriusan guru dalam mengikuti pelatihan, b) pengetahuan yang diperoleh guru tentang hakikat penelitian, c) pengetahuan guru tentang artikel ilmiah dan kaidah penulisanya, d) kompetensi guru dalam menyusun artikel ilmiah, (Sumartini et al., 2019).

Program Pengabdian Kepada Masyarakat tersebut dilaksanakan oleh Tim Program Studi Pendidikan Bahasa Indonesia pada Agustus s.d. September 2020. Waktu pelaksanaan kegiatan tersebut disesuaikan dengan situasi dan kondisi di lapangan. Pelatihan Penulisan Artikel Ilmiah Hasil PTK direncakan selama satu bulan sesuai dengan program PPM Prodi Pendidikan Bahasa Indonesia semester Gasal 2020/2021 UNIPA Surabaya.

\section{HASIL DAN PEMBAHASAN}

Pelaksanaan kegiatan ini dilaksanakan oleh TIM PPM Program Studi Pendidikan Bahasa Indonesia pada Agustus-September 2020. Waktu pelaksanaan tersebut dilakukan secara daring melalui Zoom Meeting. Pelaksanaan kegiatan PPM pelatihan Guru SMPN 1 Gresik, tersebut akan dilaksanakan bersama kegiatan penulisan artikel hasil PTK. Pelatihan tersebut direncanakan selama 1 bulan pada semester Gasal 2020-2021.

Dalam melaksanakan kegiatan pelatihan pembelajaran bahasa Indonesa di kelas dan teknik penyusunan penelitian tindakan kelas ini digunakan pendekatan pembelajaran andragogi dengan metode direct instruction dengan tahapan langkah sebagai berikut:

a. Penyajian penulisan Penelitian Tindakan Kelas materi secara interaktif;

b. Pemberian model pembelajaran dan latihan penerapan penyusunan Penelitian Tindakan Kelas;

c. Diskusi dan demonstrasi model pembelajaran;

d. Praktik aplikatif; menyusun artikel hasil Penelitian Tindakan Kelas. 


\section{Penyusunan Artikel Hasil Penelitian Tindakan Kelas}

Upaya untuk meningkatkan kemampuan dalam menulis artikel hasil Penelitian Tindakan Kelas, pada kegiatan tersebut peserta diminta untuk menyusun artikel dari hasil PTK yang telah dibuat. Adapun tahapan pada kegiatan tersebut ialah sebagai berikut.

a. Peserta merumuskan judul artikel sesuai dengan PTK yang telah disusun.

b. Peserta menyusun latar belakang mengenai judul artikel yang telah disusun, dengan memperhatikan modus, fokus, dan lokus.hal tersebut dilakukan untuk memberikan deskripsi yang jelas kepada pembeca mengenai permasalahan dan solusi yang ditawarkan, selanjutnya peserta diminta untuk menyusun kajian pustaka yang digunakan pada PTK.

c. Peserta menyusun metode penelitian; pada tahap ini peserta diminta untuk menuliskan subjek penelitian, data, serta teknik pengumpulan data dan teknik penganalisis data, serta siklus yang telah dilakukan pada kegiatan PTK.

d. Peserta menuliskan hasil penelitian; pada tahap ini peseta diminta untuk menuliskan hasil yang telah dilakukan pada setiap siklus melalui metode analisis yang telah ditentukan.

e. Peserta menuliskan hasil dan pembahasan: pada tahap ini peserta menyusun pembahasan mengani tahapan penelelitian yang telah dilakukan, serta menyusun hasil penelitian yang diperoleh, selanjutnya;

f. Peserta menyusun simpulan berdasarkan hasil pembahasan yang diperoleh, serta saran bagi penulis dari pembaca, sebagai masukan untuk perbaikan artikel yang telah disusun.

g. Peserta menyusun abstrak; dengan memperhatikan tujuan, metode, serta hasil dari penelitian yang dilakukan.

h. Menyusun daftar pustaka, mengenai semua referensi yang telah digunakan baik dari buku maupun jurnal, dengan model APA.

i. Refleksi dan evaluasi dari hasil penyusunan artikel yang telah dilakukan, untuk mengetahui kekurangan dan kelemahan sebagai upaya perbaikan untuk kegiatan pelatihan berikutnya.

Berikut akan dipaparkan mengenai hasil pelatihan yang telah dilakukan pada Guru SMPN 1 Gresik, yang telah dilakukan oleh Pogram Studi Pendidikan Bahasa Indonesia, berdasarkan evaluasi yang dilakukan terdapat beberapa hal yang dapat disimpulkan sebagai berikut; a) guru memiliki keseriusan untuk mau belajar tentang penelitian tindakan kelas dan penulisan artikel hasil peneltitian tindakan kelas, b) guru juga memiliki pemahaman yang baik tentang hakikat penelitian, utamanya penelitian tindakan kelas, c) guru juga memiliki dasar kompetensi yang baik dalam penyusunan artikel ilmiah, d) selanjutnya, guru juga dapat menyusun artikel ilmiah melalui penelitian tindakan kelas.

Selanjutnya berdasarkan pelatihan yang dilakukan terdapat dua hal yang diperoleh dari pelatihan tersebut; 1) hasi pelatihan penyusunan artikel hasil PTK ialah peserta dapat menyusun artikel ilmiah hasil PTK dengan baik. Hal tersebut dapat dibuktikan dari 40 produk artikel yang ditulis oleh Guru SMPN 1 Gresik, yang memenuhi kriteria artikel yang baik dengan memperhatikan aspek pada setiap artikel ialah sebesar 94\%. Selanjuntya sekitar $6 \%$ belum memenuhi kriteria aspek artikel yang baik selama proses pelatihan, 2) refleksi dan evaluasi pelatihan dilakukan untuk mendapatkan umpan balik dari peserta selama kegiatan berlangsung, merupakan salah satu bentuk upaya yang dilakukan untuk perbaikan kegiatan PPM berikutnya. Dalam kegiatan tersebut peserta juga diminta untuk mengisi kuisioner meliputi; materi pelatihan, pemateri, fasilitas yang disediakan. Berdasarkan pendapat serta kuisioner mengenai beberapa aspek tersebut bahwa hampir semua peserta (40 orang) dapat menyerap materi pelatihan dengan baik. Hal tersebut terbukti melalui produk artikel yang disusun oleh peserta.

\section{KESIMPULAN}

Berdasarkan hasil pelatihan dan pembahasan tersebut diperoleh simpulan, bahwa sebelum kegiatan pelatihan dilaksanakan, peserta belum memiliki pengetahuan, tentang penyusunan artikel yang sesuai dengan kriteria artikel ilmiah yang baik. Hal tersebut menyebabkan peserta enggan menulis artikel ilmiah, namun setelah peserta mengikuti pelatihan penulisan artikel hasil PTK, peseta memperoleh pengetahuan yang baik mengenai penulisan artikel ilmiah yang sesuai dengan kriteria. Sehingga, melalui kegiatan pelatihan tersebut diharapakan Guru SMPN 1 Gresik dapat termotivasi untuk lebih rutin dalam melaksakan PTK dan menyusun artikel hasil PTK secara berkala. 
Kegiatan PPM yang dilakukan oleh Program Studi Pendidikan Bahasa Indonesia, Fakultas Ilmu Sosial dan Humaniora, Univ. PGRI Adi Buana Surabaya, berjalan sesuai dengan tujuan pelatihan yang teklah ditetapkan. Hal tersebut terbukti dari hasil pelatihan yang menunjukkan bahwa 94\% Guru SMPN 1 Gresik sudah dapat menyusun artikel hasil PTK dengan baik dan sudah sesuai dengan kriteria. Selain itu, hampir semua peserta (40 orang) memberikan respon yang positif mengenai pelatihan yang telah dilakukan.

\section{REFERENSI}

Al Idrus, S. W., Anwar, Y. A. S., Hakim, A., \& Saprizal, S. (2020). Penulisan Artikel Ilmiah Sebagai Upaya Peningkatan Profesionalisme Guru Kimia SMA di Kota Mataram. Jurnal Pengabdian Masyarakat Sains Indonesia, 2(1). https://doi.org/10.29303/jpmsi.v2i1.34

Dewi, P. K., Rizal, M. S., Ardhian, D., \& Hardinata, V. (2017). Pelatihan Penulisan Artikel Ilmiah Berbasis Penelitian Tindakan Kelas Pada Guru Smp. Jurnal ABDI, $2(2), \quad 7$. https://doi.org/10.26740/ja.v2n2.p7-17

Hidayah Rusly, Dina Kartika Maharani, M. (2020). PELATIHAN PENULISAN ARTIKEL ILMIAH BERBASIS PENELITIAN TINDAKAN KELAS (PTK) BAGI GURU KIMIA SMA DI MGMP KIMIA SMA KABUPATEN KEDIRI. $\quad A b d i, \quad$ 5(PELATIHAN PENULISAN ARTIKEL ILMIAH BERBASIS PENELITIAN TINDAKAN KELAS (PTK) BAGI GURU KIMIA SMA DI MGMP KIMIA SMA KABUPATEN KEDIRI), 107-110. https://journal.unesa.ac.id/index.php/abdi/ article/view/3876

Mahmud dan Tedi Priatna. (1980). PENELITIAN TINDAKAN KELAS Teori dan Praktik. Perputakaan Nasional Dalam Terbitan, 6(1), 466.

Marwa, M., \& Dinata, M. (2020). Pelatihan Penulisan Artikel Ilmiah dan Publikasi di Jurnal bagi Guru SMAN 4 Tualang, Kabupaten Siak. Jurnal Pengabdian Pada Masyarakat, 5(1), 71-82. https://doi.org/10.30653/002.202051.256

Mulia, D. S., \& Suwarno. (2016). Ptk (Penelitian Tindakan Kelas) Dengan Pembelajaran Berbasis Kearifan Lokal Dan Penulisan Artikel Ilmiah Di Sd Negeri Kalisube, Banyumas. Khazanah Pendidikan Jurnal Ilmiah Kependidikan, Vol. IX, No. 2 (Maret 2016) PTK, IX(2), 11.

http://jurnalnasional.ump.ac.id/index.php/ khazanah/article/view/1062/983

Salim, Isran Rasyid K.K, H. (2013). Penelitian Tindakan Jelas. In Jurnal Pendidikan Penabur (Issue 12, p. 11).

Siregar, I. F. (2011). Ilmiah Untuk Jurnal Bagi Guru Guru Sekolah Dasar Kota Semarang Dalam Upaya. 15, 121-130.

Slameto, S. (2016). Penulisan Artikel Ilmiah Hasil Penelitian Tindakan Kelas. Scholaria: Jurnal Pendidikan Dan Kebudayaan, 6(2), 46. https://doi.org/10.24246/j.scholaria.2016. v6.i2.p46-57

Sumartini, Mulyani, M., \& Nugroho, B. A. (2019). Workshop Penulisan Karya Ilmiah Bagi Guru. Jurnal Puruhita, 1(1), 54-59. https://journal.unnes.ac.id/sju/index.php/p uruhita/ 